\title{
Effect of Compost Made from Decomposing Cocoa Pod and Animal Dung on the Yield of Maize Crop
} Adegunloye, D. V' ${ }^{1}$ Olotu, T. M ${ }^{2}$

\author{
${ }^{1}$ Department of Microbiology, School of Sciences, Federal University of Technology Akure, P.M.B 704, Akure, Ondo state, \\ Nigeria. \\ ${ }^{2}$ Department of Microbiology, Faculty of Science, Adeleke Univers ity, P.M.B 250. Ede, Osun State, Nigeria.
}

\begin{abstract}
Ondo State has the largest production of cocoa in Nigeria, cocoa pod on most cocoa plantation in the state are usually left as an environmental nuisance on the cocoa plantation. Effect of compost made from decomposing cocoapod and animal dung on the yield of maize crop were investigated for nine weeks. Cocoa pods were decomposed using animal dung (poultry droppings, pig and cow dung) in ratio 3:1 of cocoa pod to each of the animal dung. Cocoa pod and poultry droppings mixture has the highest bacterial, fungal and yeast population of $2.6 \times 10^{6}-2.9 \times$ $10^{6}(\mathrm{cfu} / \mathrm{ml}), 8.4 \times 10^{5}-9.2 \times 10^{5}(\mathrm{sfu} / \mathrm{ml})$ and $4.0 \times 10^{4}-12.0$ $x 10^{4}(\mathrm{cfu} / \mathrm{ml})$. It also had the highest moisture content $(88.81 \%)$ and temperature $\left(35^{\circ} \mathrm{C}\right)$ among the composting materials. Fifteen bacteria and thirteen fungi were isolated during the decomposition; common microorganisms that occur throughout decomposition were Bacillus sp, Pseudomonas sp, Escherichia coli, Staphylococus aureus, Serratia Sp, Fusarium sp, Mucor sp, Tricoderma sp, Aspergillus sp, Cladosporum sp and Neurospora sp. The $\mathrm{pH}$ of decomposing samples ranged from 6.10 to 7.81 at the initial stage of decomposition and pH of 7.79-9.07 at maturity of the compost. Poultry cocoa compost has the highest NPK (nitrogen, phosphorus and potassium) content of $1.345,7.955$ and $23.016(\mathrm{mg} / \mathrm{kg})$ respectively. Experimental setup was carried out in the field and in the screen house which the cocoa pod compost and NPK fertilizer was use to plant yellow and white maize. The compost fertilizer had a better better output than the NPK fertilizer. Height-350cm, grithy-8cm, cob-15 (big and strong) colour of maize plant (deep green leaves) while height-320cm, grith $-4 \mathrm{~cm}$, cob-10 (small and colour of maize plant (greenish yellow leaves) for the cocoa compost and NPK fertilizer respectively were at the field Cocoa pod and poultry droppings mixture has the highest of the yellow and white maize $(136 \mathrm{~cm}$ and $126 \mathrm{~cm})$ respectively while the
\end{abstract}

NPK sample has the lowest height of $55 \mathrm{~cm}$ and $50 \mathrm{~cm}$ respectively of yellow and white maize.

Keywords-Microorganisms, Composting, Decomposition, Cocoa pod wastes, Occurrence, screen house and NPK fertilizer.

\section{INTRODUCTION}

Composting occurs through the activity of microorganisms naturally found in soils. Under natural conditions, earthworms, nematodes and soil insects such as mites, sowbugs, ants, and beetles do most of the initial mechanical breakdown of organic materials into smaller particles. Under controlled conditions, composters break down large particles through grinding or chopping. Once optimal physical conditions are established, soil bacteria, fungi, actinomycetes and protozoa colonize the organic material and initiate the composting process. These mesophilic organisms function best at warm temperatures $\left(10-45^{\circ} \mathrm{C}\right)$ [1]. Poultry droppings are the feces of chickens used as an organic fertilizer, especially for soil low in nitrogen. Of all animal manures, it has the highest amount of nitrogen, phosphorus, and potassium [2].Cacao (Theobroma cacao.L) belongs to the genus Theobroma classified under the subfamily Sterculioidea of the mallow family Malvaceae [3] A cocoa pod (fruit) has a rough and leathery rind about 3 $\mathrm{cm}$ thick (this varies with the origin and variety of pod). It is filled with sweet, mucilaginous pulp enclosing 30 to 50 large seeds that are fairly soft and white to a pale lavender color. While seeds are usually white, they become violet or reddish brown during the drying process [4]. The animal dung added to cocoa pod is to serve as a booster which hastens the rate of decomposition of the pod waste, both serves as carbon and nitrogen sources decomposing microorganisms in the production of the compost [5]. The aims of this research therefore are determination of microbial population, microbial identification, and 
frequency of occurrence of microorganisms that decomposed the wastes. Moisture content, $\mathrm{pH}$ and temperature of the composing materials during decomposition are also examined.

\section{METHODS}

\subsection{Sources and collection of materials}

The organic waste used for the production of the biofertilizer was cocoa pod waste and animal dung which were poultry droppings, cow and pig dung. The cocoa pod waste was obtained from Ajipowo Farm at Idanre in Ondo State and the animal dungs were collected from an agricultural farm at Oba-Ile, Akure. The decomposition of the organic wastes was carried out at the screen house using the windrow method.

2.2 Compost preparations: The pod wastes was cut to smaller pieces of $5 \mathrm{~cm}$ breadth and length and five samples were made of the decomposing materials formations which were mixed in 3:1 according to the research of [6]. Each sample contains $25 \mathrm{~kg}$ of cocoa pod waste and $8.3 \mathrm{~kg}$ of animal dung. The samples were mixed as follows; cocoa pod waste and poultry droppings, cocoa pod waste and pig dung, cocoa pod waste and cow dung and cocoa pod waste and combination of each of the animal dung. The pod waste and the animal dung of each of the samples were mixed thoroughly together and watered, turning of the compost was done every five days using shovel for nine weeks.

\subsection{Microbial and physiochemical analyses}

Microbial identification was determined on each organic waste to be decomposed. Microbial load, $\mathrm{pH}$, temperature and moisture content were carried out at the first week of decomposition and throughout the period of decomposition (nine weeks) on a weekly basis [6]. The temperature of the decomposing materials was measured using Mercury thermometer graduated in degree centigrade. The $\mathrm{pH}$ of the decomposing materials was determined at the first week of decomposition and at the subsequent weeks. The $\mathrm{pH}$ was determined using a glass electrode $\mathrm{pH}$ meter. The microorganisms which were mainly bacteria, fungi and yeast were isolated using nutrient agar, marconkey agar, eosin methyl blue and potato dextrose agar. Samples were collected from decomposing materials using sterile spatula into a sterile beaker and sealed tightly prior to microbial analyses. Bacteria were isolated and identified according to [7].

2.4 Experimental sites: The experimental sites was used for these research to observe the effects of the cocoa compost samples produced White and Yellow maize grains was planted on the field and the Screen house. At the Field Yellow (SWAN 1) and white (DMRLSR WHITE) maize grains was planted. The treatments applied were Yellow and white maize grains planted with each of the various treatments. At the Screen house, Soil was taken from the field and were sterilized at $180^{\circ} \mathrm{C}$ for $3 \mathrm{hrs}$ in an Hot air oven and when cooled, Mineral analysis of the sterilized soil was determined before using it to plant, $1 \mathrm{~kg}$ of the sterilized soil was poured into buckets and labeled according to the treatments to be applied. Five grams of each treatment were applied into each labeled buckets and the Yellow (SWAN 1) and White (DMRLSR WHITE) maize grains were planted for four weeks.

2.5 Field management and planting: Three seeds of the Yellow and White maize grains were planted per hole to a depth of $3-4 \mathrm{~cm}$ at $60 \mathrm{~cm}$ intra space and $90 \mathrm{~cm}$ inter space; each samples of the cocoa compost were incorporated in to the soil as labeled on the rows. Nitrogen, Phosphorous and Potassium (NPK) fertilizer was applied at the fourth week of planting for planting on the field and at the second week of planting in the screen house NPK fertilizer was also applied. Height of each plant on the field and the screen house were measured weekly and recorded using measuring rule.

\section{RESULT/ DISCUSSION}

The bacterial, fungal and yeast population of the composting materials as illustrated in Figures 1, 2 and 3 show the population of the various samples, control (cocoa pod waste only), cocoa pod and pig dung, cocoa pod and poultry droppings, cocoa pod and cow dung and cocoa pod and combination of all the animal dung. In all the samples there was a general rapid increase in the microbial population from the first week of decomposition to the third, from fourth till maturity, there was a decrease in the microbial population.

Bacterial population of the various samples (Figure 1) ranged from $2.2 \times 10^{6}$ to $1.5 \times 10^{6}(\mathrm{cfu} / \mathrm{ml})$ from the $\mathrm{Al}$ sample to the Po sample. Fungal population (Figure 2) of ranged from $7.8 \times 10^{5} \mathrm{sfu} / \mathrm{ml}$ to $3.8 \times 10^{5} \mathrm{sfu} / \mathrm{ml}$ from the $\mathrm{Al}$ sample to the Po sample. Yeast population (Figure 3) ranged from $12 \times 10^{4}$ to $3 \times 10^{4}(\mathrm{cfu} / \mathrm{ml})$ from the Al sample to the Po sample. Yeast growth was observed only at first three weeks, at the later weeks of decomposition there was no growth. Cocoa pod and poultry droppings mixture has the highest bacterial, fungal and yeast population of 2.6 $\mathrm{x} 10^{6}-2.9 \times 10^{6}(\mathrm{cfu} / \mathrm{ml}), 8.4 \times 10^{5}-9.2 \times 10^{5}(\mathrm{sfu} / \mathrm{ml})$ and $4.0 \times 10^{4}-12.0 \times 10^{4}(\mathrm{cfu} / \mathrm{ml})$. Percentage frequency of occurrence of the bacteria, fungi and yeast isolated during decomposition as represented in Tables 1 and 2. Among the bacterial population, Bacillus sp and Echerichia coli has the highest percentage frequency of occurrence of $11.7 \%$ while 
Micrococcus sp and Lactobacillus sp has the lowest of $2.6 \%$ and among the fungal population Aspergillus flavus and Fusarium sporotrichoides has the highest percentage frequency of occurrence of $11.1 \%$ while Pennicillum notatum has the lowest of $2.5 \%$.

Weekly moisture content of the decomposing materials during decomposition is shown in Figure 4. The moisture content of the samples was considerably high in the first four weeks of decomposition after which it decreased gradually in the later weeks. The cocoa pod and combination of all the animal dung (Al sample) had the highest moisture content of $86.06^{\mathrm{c}} \pm 0.01$ to $82.75^{\mathrm{d}} \pm 0.11$ at the first to third week of decomposition. The control (cocoa pod only) had the lowest moisture content of $74.36^{\mathrm{a}} \pm 0.02$ to $63.40^{\mathrm{b}} \pm 0.10$ from the first to ninth week of decomposition. The cocoa pod and poultry dropping sample had the lowest moisture content of $61.99^{\mathrm{a}} \pm 1.14$ at the ninth week of decomposition. The $\mathrm{pH}$ of the various decomposing materials (Figure 5) was relatively low at the early weeks of decomposition (week 1 to 6) and was alkali at latter weeks.

\section{Result and Discussion}

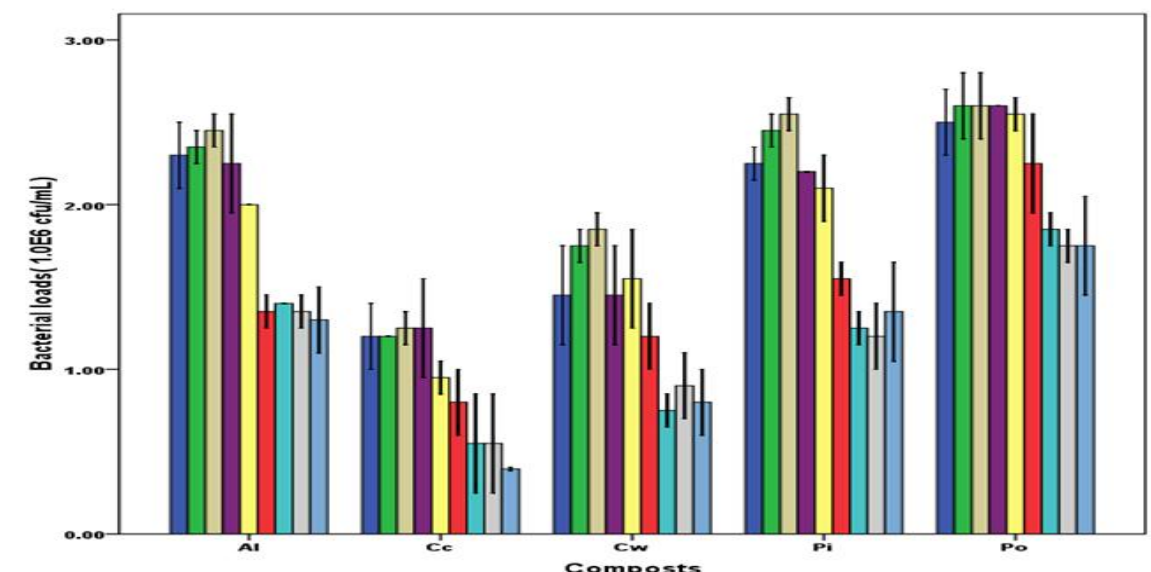

Figure 1: Weekly bacterial population of composting materials KEYS: CC-Control during decomposition (cfu/ml)

Pi-Cocoa pod and Pig dung

Po-Cocoa pod and Poultry droppings

Cw-Cocoa pod and Cow dung

Al-Cocoa pod, Poultry droppings, Pig and Cow dung
The control (cocoa pod only) had highest acidic $\mathrm{pH}$ of 6.10 6.08 at the first and second week of decomposition. The cocoa pod and poultry dropping (Po sample) had a neutral of 7.26-7.08 at the first and second week of decomposition. At the maturity of the biofertilizer the $\mathrm{pH}$ of the various samples are alkali and control has the highest alkali $\mathrm{pH}$ of 9.07 .

There was a general rise in temperature of the sample (Figure 6) in the first three weeks of decomposition and decreased gradually until maturity. Cocoa pod and poultry droppings had the highest temperature of $35^{\circ} \mathrm{C}$ on first weeks of decomposition to $27^{\circ} \mathrm{C}$ at maturity while control which is only cocoa pod waste had the lowest temperature of $29^{\circ} \mathrm{C}$ at the first week of decomposition to $27^{\circ} \mathrm{C}$ at maturity. Mineral composition of the matured biofertilizer as presented in Table 3 shows the mineral composition of each of the biortilizers samples. Poultry biofertilizer has the highest NPK (nitrogen, phosphorus and potassium) content of $1.345,7.955$ and $23.016(\mathrm{mg} / \mathrm{kg})$ respectively. 


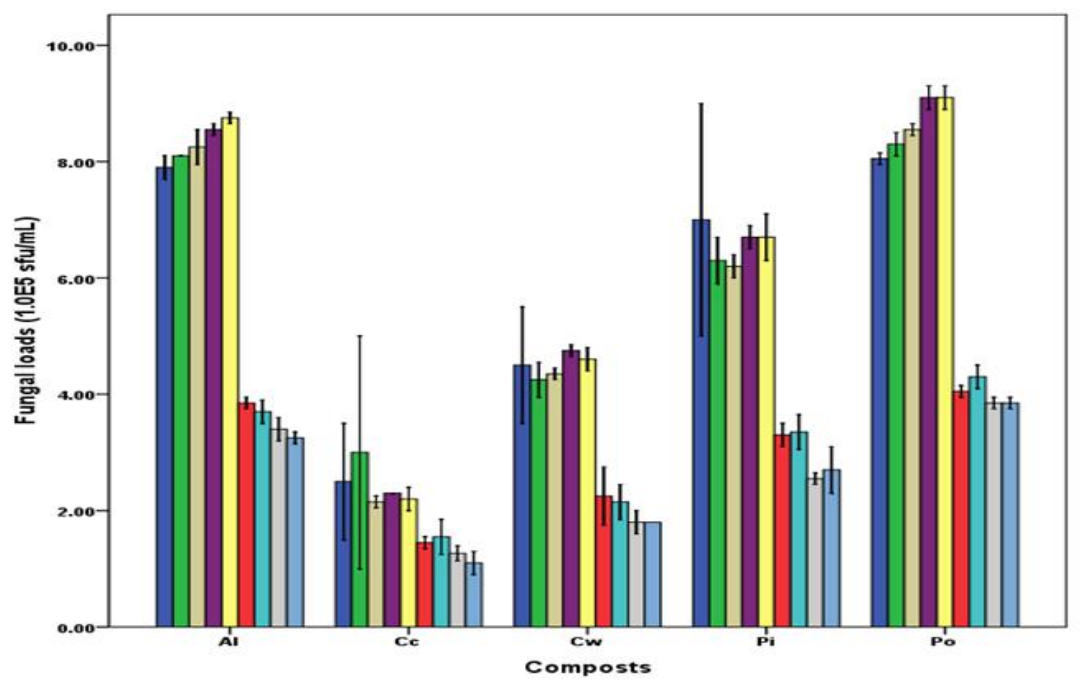

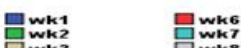

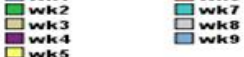

Figure 2: Weekly fungal population of composting materials during decomposition (sfu/ml)

KEYS: Cc-Control

Pi- Cocoa pod and Pig dung

Po-Cocoa pod and Poultry droppings

Cw- Cocoa pod and Cow dung

Al-Cocoa pod, Poultry droppings, Pig and Cow dung

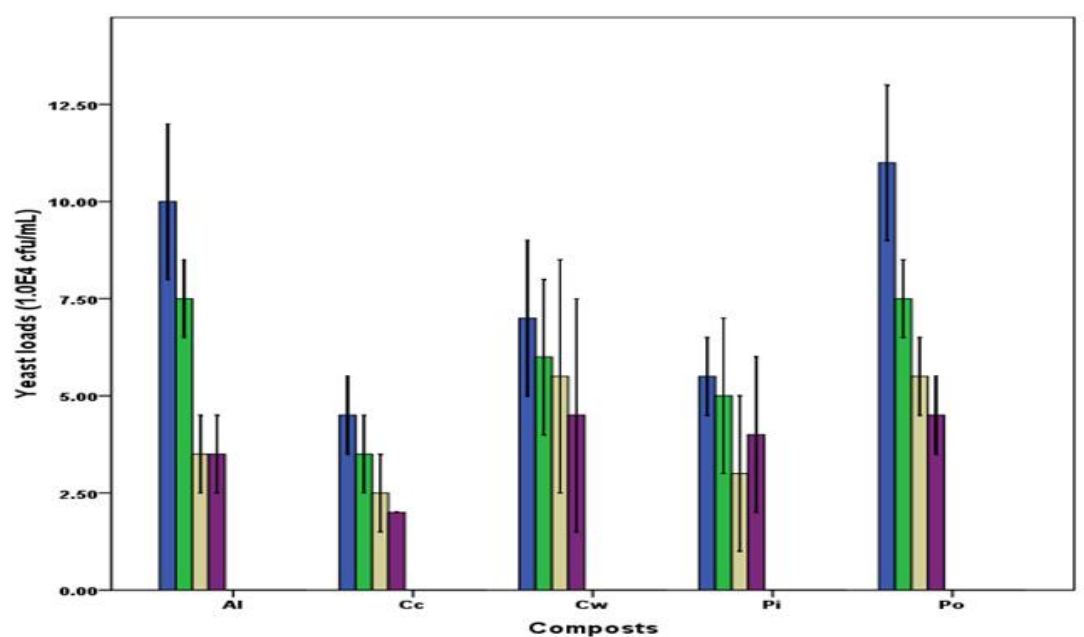

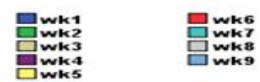

Figure 3:Weekly yeast population of composting materials during decomposition (cfu/ml)

KEYS: Cc-Control

Pi-Cocoa pod and Pig dung

Po-Cocoa pod and Poultry droppings

Cw- Cocoa pod and Cow dung

Al-Cocoa pod, Poultry droppings, Pig and Cow dung 
Table 1: percentage frequency of occurrence of bacteria during decomposition

\begin{tabular}{|c|c|c|c|c|c|c|c|c|c|c|c|}
\hline IS & WK 1 & WK2 & WK3 & WK4 & WK5 & WKG & WK7 & WK 8 & WKo & $\mathbf{T N}$ & $\%$ o \\
\hline A & + & + & + & + & + & + & + & + & + & 9 & 11.7 \\
\hline $\mathbf{B}$ & + & + & - & - & - & - & - & - & - & 2 & 2.6 \\
\hline C & - & - & + & + & + & + & + & + & + & 7 & 9.1 \\
\hline D & - & - & - & + & + & + & + & + & + & 6 & 7.8 \\
\hline $\mathbf{E}$ & + & + & - & - & - & - & - & - & - & 2 & 2.6 \\
\hline $\mathbf{F}$ & - & - & - & - & + & + & + & + & + & 5 & 6.5 \\
\hline G & + & + & + & + & + & + & + & + & + & 9 & 11.7 \\
\hline $\mathbf{H}$ & - & + & + & + & - & - & - & - & - & 3 & 3.9 \\
\hline $\mathbf{I}$ & - & + & + & + & + & + & + & - & - & 6 & 7.8 \\
\hline $\mathbf{J}$ & + & + & + & - & - & - & - & - & - & 3 & 3.9 \\
\hline $\mathbf{K}$ & + & + & + & + & - & - & - & - & - & 4 & 5.2 \\
\hline $\mathbf{L}$ & + & + & + & + & + & + & + & - & - & 7 & 9.1 \\
\hline $\mathbf{M}$ & - & + & + & + & - & - & - & - & - & 3 & 3.9 \\
\hline $\mathbf{N}$ & - & + & + & + & + & + & + & + & + & 8 & 10.4 \\
\hline $\mathbf{O}$ & + & + & + & - & - & - & - & - & - & 3 & 3.9 \\
\hline
\end{tabular}

Keys:--Present , --Not detected, TN-Total number of isolate (77), IS-Probable organisms, A- Bacillus sp, B- Micrococcus sp, C- Pseudomonas sp D-Bacillus sp, E- Lactobacillus sp, F-Proteus sp G- Escherichia coli, H- Salmonella sp I- Bacillus sp J-Actinomyces sp, K- Enterobacter sp, L- Staphylococcus sp, M- Pseudomonas sp, N-Serratia spand O- Klebisella sp.

Table 2: percentage frequency of occurrence of fungi and yeast during decomposition

\begin{tabular}{|c|c|c|c|c|c|c|c|c|c|c|c|}
\hline IS & WK 1 & WK2 & WK3 & WK4 & WK5 & WKG & WK7 & WKs & WK9 & $\mathbf{T N}$ & $\%$ of \\
\hline A & + & + & + & + & + & + & + & + & + & 9 & 11.1 \\
\hline B & - & + & + & + & + & + & + & + & + & 8 & 9.9 \\
\hline C & + & + & + & + & + & + & + & - & - & 7 & 8.6 \\
\hline $\mathbf{D}$ & + & + & + & + & + & + & + & + & + & 9 & 11.1 \\
\hline $\mathbf{E}$ & - & + & + & + & - & - & - & - & - & 3 & 3.7 \\
\hline $\mathbf{F}$ & - & - & - & + & + & + & + & + & + & 6 & 7.4 \\
\hline $\mathbf{G}$ & + & + & + & + & - & - & - & - & - & 4 & 4.9 \\
\hline $\mathbf{H}$ & + & + & + & + & - & - & - & - & - & 4 & 4.9 \\
\hline $\mathbf{I}$ & - & - & - & - & + & + & + & + & - & 5 & 6.2 \\
\hline $\mathbf{J}$ & - & + & + & - & - & - & - & - & - & 2 & 2.5 \\
\hline $\mathbf{K}$ & - & + & + & + & + & + & + & + & + & 8 & 9.9 \\
\hline $\mathbf{L}$ & - & - & - & - & - & - & + & + & - & 3 & 3.7 \\
\hline M & - & - & - & - & - & - & + & + & - & 5 & 6.2 \\
\hline $\mathbf{N}$ & - & - & - & - & + & + & + & + & + & 4 & 4.9 \\
\hline O & + & + & + & + & - & - & - & - & - & $\begin{array}{l}4 \\
(81)\end{array}$ & $\begin{array}{l}4.9 \\
100\end{array}$ \\
\hline
\end{tabular}

Keys: +-Present, --Not detected, TN-Total number of isolate present(81), IS-Probable organisms. A- Fusarium sporotrichoides, B- Mucor mucedo, C-Tricoderma viride, D- Aspergillus flavus, E-Articulospora inflata, F-Cladosporium species,G- Rhizopus nigiricans, H-Aspergillus niger, I- Aspergillus fumigatusJ- Penicillum notatum, K- Neurospora crassa, L- Geonabotobotryum apiculatum, M- Penicillum italicum, N-Sacchromyces cerevisae, O-Schizosacchromyces pombe 


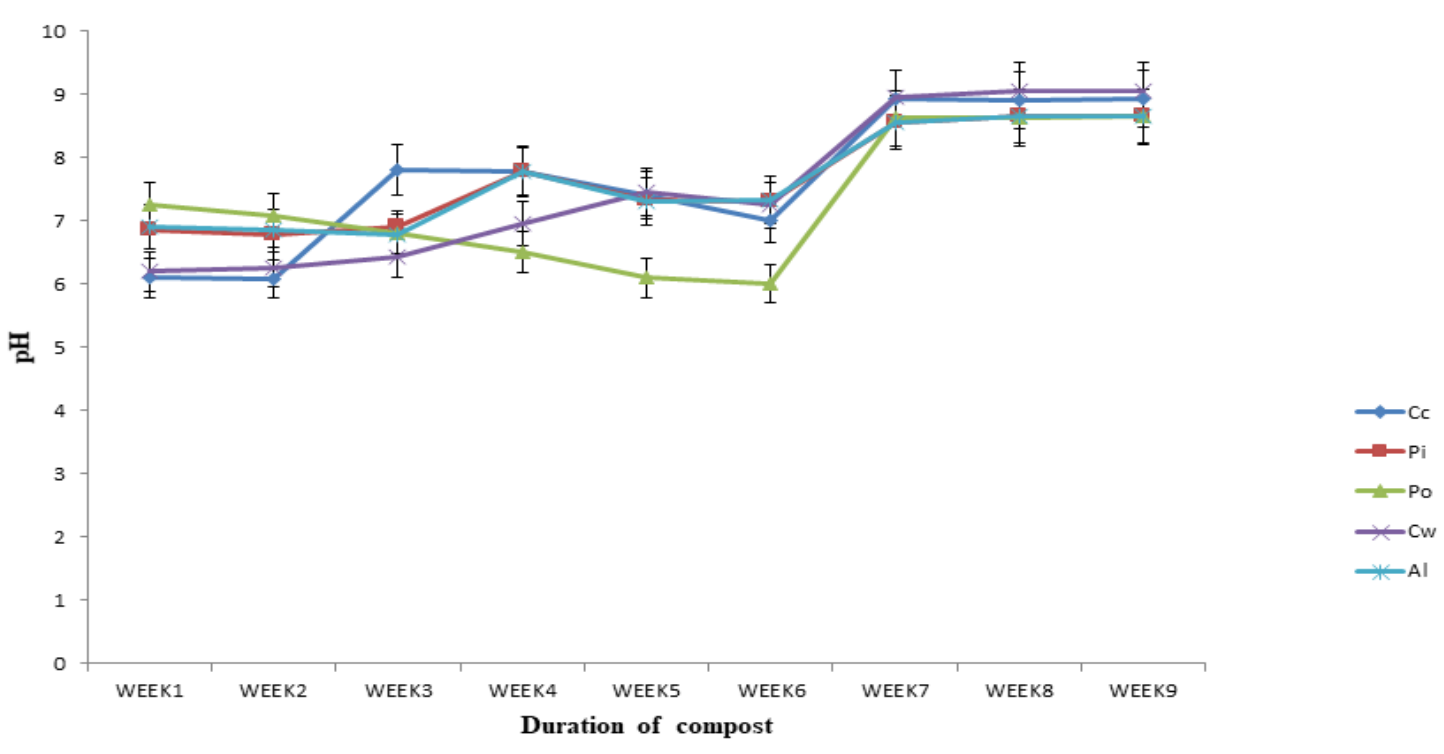

Figure 4: Weekly pH of the decomposing materials

KEYS: CC-CONTROL, PI-Cocoa pod and pig dung, PO-Cocoapod and Poultry dung, Cw-Cocoa pod and Cow dung, ALL-Cocoa pod, Poultry droppings, Pig and Cow dung.

\section{Table 3: Proximate composition of the matured biofertilizer}

\begin{tabular}{|c|c|c|c|c|c|c|}
\hline SAMPLE & MOISTURE $\%$ & FAT $\%$ & ASH \% & CRUDE FIBRE $\%$ & PROTEIN \% & $\mathrm{CHO} \%$ \\
\hline $\mathrm{Cc}$ & $56.34^{a} \pm 0.04$ & $5.05^{a} \pm 0.01$ & $5.38^{\mathrm{a}} \pm 0.06$ & $7.74^{b} \pm 0.09$ & $6.75^{a} \pm 0.03$ & $13.63^{d_{ \pm}} \pm 0.05$ \\
\hline $\mathbf{P i}$ & $62.33^{e} \pm 0.10$ & $6.40^{b} \pm 0.52$ & $6.43^{b} \pm 0.12$ & $8.28^{c} \pm 0.03$ & $7.69^{b} \pm 0.06$ & $10.38^{b} \pm 0.05$ \\
\hline Po & $62.19^{d} \pm 0.0^{7}$ & $7.01^{b} \pm 0.08$ & $6.39^{b} \pm 0.15$ & $9.32^{\mathrm{a}} \pm 0.05$ & $9.26^{e} \pm 0.01$ & $10.85^{\circ} \pm 0.03$ \\
\hline $\mathrm{Cw}$ & $57.26^{b} \pm 0.11$ & $5.22^{\mathrm{a}} \pm 0.10$ & $7.86^{\complement} \pm 0.10$ & $9.32^{\mathrm{d}} \pm 0.02$ & $7.40^{<} \pm 0.00$ & $7.21^{\mathrm{a}} \pm 0.02$ \\
\hline Al & $59.67^{c} \pm 0.15$ & $6.33^{\mathrm{c \pm} 0.17}$ & $5.50^{\mathrm{a}} \pm 0.03$ & $8.50^{p} \pm 0.03$ & $8.24^{d} \pm 0.03$ & $13.63^{\circ} \pm 0.0$ \\
\hline
\end{tabular}

KEYS: Cc-Control, Pi-Cocoa pod and Pig dung, Po-Cocoa pod and Poultry droppings, Cw-Cocoa pod and Cow dung, Al- Cocoa pod, Poultry droppings, Pig and Cow dung. 


\section{Table 4: Mineral commosition of the}

\begin{tabular}{|c|c|c|c|c|c|c|c|c|}
\hline Treatments & $\mathrm{Na}(\mathbf{m g} / \mathbf{k g})$ & $\mathbf{M g}(\mathbf{m g} / \mathbf{k g})$ & $\mathrm{Ca}(\mathrm{mg} / \mathrm{kg})$ & $\mathbf{K}(\mathbf{m g} / \mathbf{k g})$ & $\mathbf{Z n}(\mathbf{m g} / \mathbf{k g})$ & $\mathbf{C u}(\mathbf{m g} / \mathbf{k g})$ & $\mathbf{P}(\mathbf{m g} / \mathbf{k g})$ & $N(\%)$ \\
\hline $\mathrm{Ce}$ & $0.836^{2} \pm 0.01$ & I. $507 \pm 0.00$ & $0.327 d \pm 0.00$ & $10.526^{m} \pm 0.04$ & $1.430^{d} \pm 0.01$ & $0.705^{2} \pm 0.51$ & $6.143^{\circ} \pm 0.02$ & $1.030^{\circ} \pm 0.01$ \\
\hline $\mathbf{P i}$ & $1.002 c \pm 0.00$ & $0.927=000$ & $0.322 \pm 0.00$ & $16.29 .4 \div \pm 0.00$ & $0.660^{b} \pm 0.01$ & $0.105^{2} \pm 0.01$ & $3.670^{5} \pm 0.01$ & $1.203^{b} \pm 0.01$ \\
\hline Po & $0.967^{b} \pm 0.01$ & $5.089^{4} \pm 0.01$ & $0.329^{d} \pm 0.00$ & $23.016^{\circ} \pm 0.00$ & $1.620^{\circ} \pm 0.01$ & $0.135^{2} \pm 0.01$ & $7.955^{4} \pm 0.04$ & 1.34540 .01 \\
\hline $\mathrm{Cw}$ & $1.077^{4} \pm 0.00$ & $1.320^{b} \pm 0.00$ & $0.309^{*} \pm 0.00$ & $13.065^{b} \pm 0.01$ & $0.435^{\circ} \pm 0.01$ & $0.080^{2} \pm 0.00$ & $3.744^{b} \pm 0.00$ & $1.245 \pm 0.01$ \\
\hline Al & $1.055^{d} \pm 0.00$ & $2.113^{4} \pm 0.00$ & $0.318^{b} \pm 0.00$ & $16952^{d} \pm 0.03$ & $1.025 \div 0.01$ & Nd & $3.403^{2} \pm 0.00$ & $1.490^{\circ} \pm 0.01$ \\
\hline
\end{tabular}

KEYS: Cc-Control, Pi-Cocoa pod and Pig dung, Po-Cocoa pod and Poultry droppings, $\mathrm{Cw}-\mathrm{Cocoa}$ pod and Cow dung, Al-Cocoa pod, Poultry droppings, Pig and Cow dung.

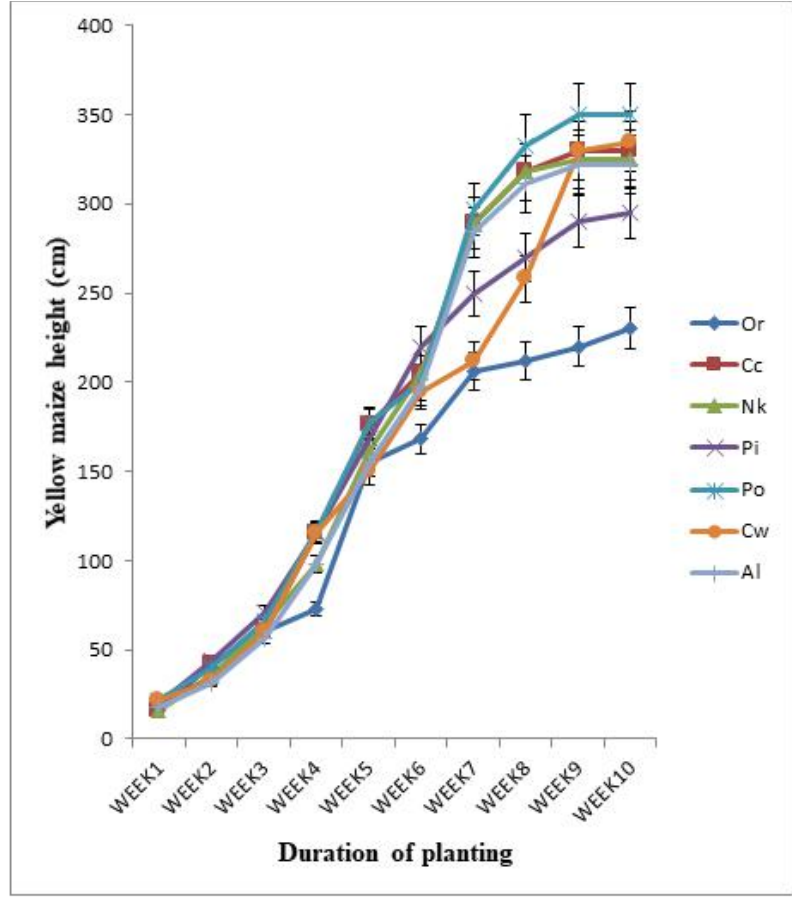

Yellow maize

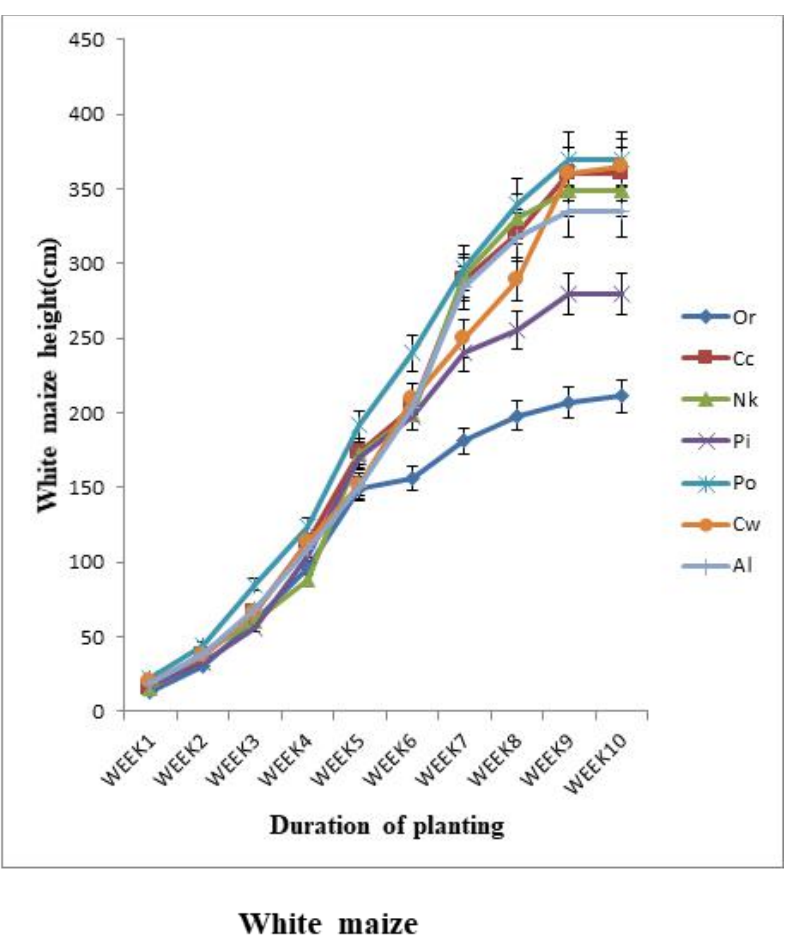

White maize

Figure 5: Comparison between the heights of the Maize on the field

KEYS: Or-Control, CC-Cocoa pod only, Nk-NPK treatment, PO-Cocoa pod and Poultry droppings, PI- Cocoa pod and Pig dung, Cw- Cocoa pod and Cow dung, AL-Cocoa pod and Poultry droppings, Cow and Pig dung. 
Table 5: Yeilds of Maize planted on the field at maturity

TREATMENT

PO

PI

ALL

$\mathbf{C W}$

$\mathbf{C C}$

NPK

ORD
YELLOW MAIZE

$300 g$

$\operatorname{200g}$

$180 \mathrm{~g}$

2009

$170 g$

$160 \mathrm{~g}$

$\mathbf{8 0 g}$
WHITE MAIZE

$250 g$

$170 g$

$\mathbf{2 0 0 g}$

$250 g$

$160 \mathrm{~g}$

$150 \mathrm{~g}$

$90 g$

KEYS: ORD- Maize planted without any treatment, $C$ C-Cocoa pod only, Nk-NPK treatment, PI-Cocoa pod and Pig dung, Po-Cocoa pod and Poultry dung, CwCocoa pod and Cow dung, AL-Cocoa pod and Poultry droppings, Cow and Pig dung.

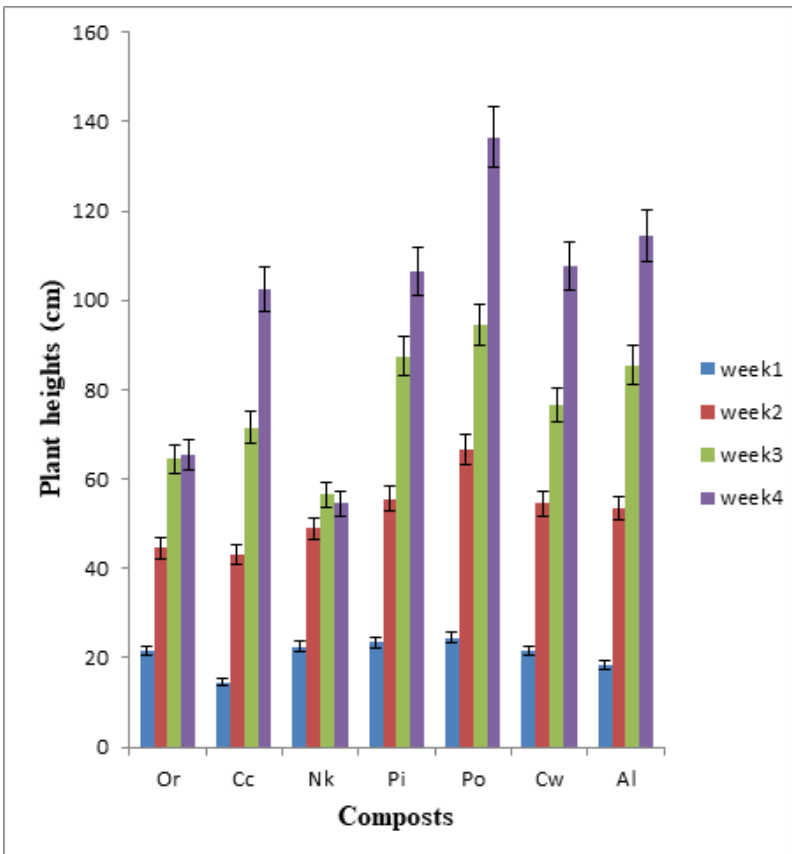

Yellow maize

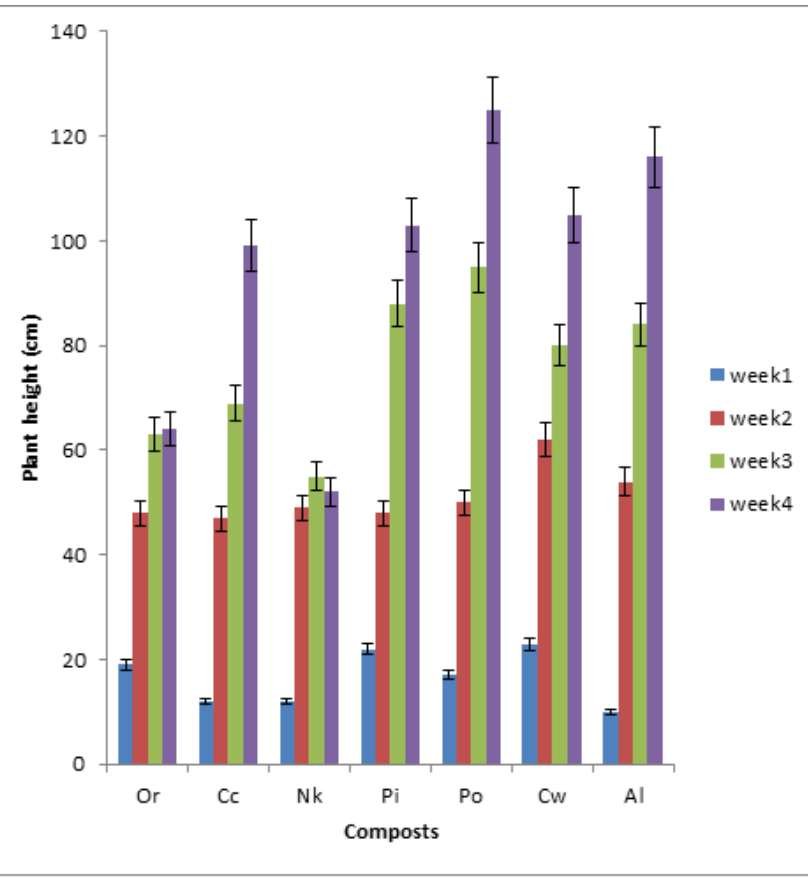

white maize

Figure 6: comparison between the heights of the Yellow and White maize in the screen house

Keys: Or-Control, CC-Cocoa pod only, Nk-Nitrogen Potassium Calcium treatment, PO-Cocoa pod and Poultry droppings, PI- Cocoa pod and Pig dung, Cw- Cocoa pod and Cow dung, AL- Cocoa pod and Poultry droppings, Cow and Pig dung.

In all the samples (Figures 1 - 3) there was general increase in the bacterial, fungal and yeast population at the early weeks of decomposition from the first week of decomposition (week 1-4) and at the later weeks there was a decrease in the microbial population. The initial increase might be due to the presence of high level of carbon and nitrogen present in the composting materials which favour the bacterial, fungal and yeast population. The decrease in the microbial population at the later weeks might be attributed to low level of nutrient present in the compost 
due to the utilization of the nutrients by the microorganisms in the compost pile and the physicochemical parameters of the composing materials might not favour the increase in growth of these microorganisms at maturity (Hargerty et al. (1999). Among all the composing samples cocoa pod and poultry droppings sample has the highest bacterial, fungal and yeast population during decomposition, this might have resulted from high level of nutrient present in the poultry dropping which was higher than other nitrogen sources used.

The percentage frequency of occurrence (Tables 1 and 2) of the bacteria, fungi and yeast isolated during decomposition, showed the microorganisms with the highest frequency of occurrence were Bacillus sp Echerichia coli, Aspergillus flavus and Fusarium sporotrichoides of 11.7\%, $11.7 \%$, $11.1 \%$ and $11.1 \%$ occurrence respectively while Micrococcus sp, Lactobacillus sp and Penicillium notatum has the lowest percentage frequency of occurrence of $2.6 \%$, $2.6 \%$ and $2.5 \%$ respectively. This probably could have been aided by the ability of these microbes to be able survive mesophilic range of temperature, the near fairly neutral to alkaline $\mathrm{pH}$ of the compost system and the moderately high moisture content of the compost system this agrees with Blanc et al., (1997). The $\mathrm{pH}$ of the various samples (Figure 4) was neutral at the first week to the sixth week of decomposition and at the later weeks was alkali. At the early stage of the decomposing materials the release of organic acid may temporarily lower the $\mathrm{pH}$ (acidity) and production of ammonia from nitrogenous compounds may raise the $\mathrm{pH}$ (alkalinity) (Haug and Roger, 1994). There was a general rise in temperature of the samples of composing materials (Figure 6) in the first three weeks of decomposition and decrease gradually until maturity. The mineral composition of the various samples of the matured cocoa compost (Tables 4) showed a high level of nitrogen, phosphorus and potassium content. Poultry cocoa compost has the highest NPK (nitrogen, phosphorus and potassium) content.

\section{CONCLUSION}

Production of high quality humic substances from cocoa pod using various animal wastes as a booster was enhanced by activities of microorganisms, the physiochemical condition and chemical composition of the organic materials. Proper moisture, correct carbon to nitrogen ratio, frequent aeration ensures early maturity of the coca compsot. The organic materials used in the cocoa compost production process were converted to rich humic substances; hence an excellent waste recycling process and most importantly will help to substitute the use of chemical fertilizer which has altered most agricultural farmlands. The poultry droppings and cocoa pod has the best output when used for planting than the other animal dungs.

\section{REFERENCES}

[1] Lopez, R. J. and Baptista, M. (1996). A preliminary comparative study of three manure composting systems and their influence on process parameters and methane emissions. Compost Science and Utilization Vol. 4, No. 3: 71-82.

[2] Patterson, P.H., E.S. Lorenz, and W.D. Weaver, Jr. 1998. Litter Production and Nutrients from Commercial Broiler Chickens. Journal of Applied Poultry Research, 7:247-252.

[3] Juan, C. Motamayor, P. L., Jay, W, Rey, L., David, N., Kuhn, J. Steven, B. and Raymond, J. (2008). "Geographic and Genetic Population Differentiation of the Amazonian ". PLoS ONE 3 (10).

[4] Terry G. Powis, W., Jeffrey, H., María, C. R., Ponciano, O. C., Michael, B., David C., Michael D. C. and John G. H. (December 2007). "Oldest chocolate in the New World". Antiquity 81 (314). ISSN 0003598X. Retrieved 2011-02-15.

[5] Lopez, R. J. and Baptista, M. (1996). A preliminary comparative study of three manure composting systems and their influence on process parameters and methane emissions. Compost Science and Utilization Vol. 4, No. 3: 71-82

[6] Adegunloye, D. V., Adetuyi, F. C., Akinyosoye F. A., and Doyeni, M.O. (2007). Microbial Analysis of compost Using Cowdung as Booster. Pakistan Journal of Nutrition. 6(5): 506-510.

[7] O.B., B., K.J, O., M.O, A., \& Y.A., B. (2017). Impact of Rotten Cocoa POD on Soil Microorganisms from Ikeji-Arakeji Metropolis, Osun State, Nigeria. International Journal Of Horticulture, Agriculture And Food Science, 1(4), 24-28. doi: 10.22161/ijhaf.1.4.4

[8] Holt, J. G., Krieg, N. R., Sneath, P. H., Stanley, J .J. and Williams, S. T. (1994). Bergeys manual of determination bacteriology. Wilkins Publishers, Baltimore, $5^{\text {th }}$ Edition. Pg 34-95. 